\title{
Familial Occurrence of Dentin Dysplasia Type I: Case Report
}

\author{
Sohyun Kim, Youngjin Kim, Hyunjung Kim, Soonhyeun Nam
}

Department of Pediatric Dentistry, School of Dentistry, Kyungpook National University

\section{Abstract}

Dentin dysplasia is a rare hereditary disturbance characterized by a dental anomaly of the dentin layer. The etiology is unclear, and this rare hereditary disturbance affects approximately one person in every 100,000. Dentin dysplasia is classified into two types, radicular dentin dysplasia as type I and coronal dentin dysplasia as type II. The characteristic clinical findings of dentin dysplasia type I are normal appearance of the crown and hypermobility of teeth. The radiographic findings are obliteration of all pulp canals, short, blunted and malformed or absent roots. Dentin dysplasia type II as coronal dentin dysplasia shows similar clinical features with dentinogensis imperfecta.

This report shows a case of dentin dysplasia type I affecting one family except the father. The clinical, radiographic and histopathologic findings of this family are presented.

Dentin dysplasia type I is difficult to diagnose unless dentist performs radiographic examination. If the affecting patient does not get regular dental care, dental abscesses or cysts may form spontaneously without caries. In this regard, early diagnosis is important to prevent premature loss of dentition.
\end{abstract}

Key words : Dentin dysplasia, Hereditary disorder, Rootless teeth

\section{I. 서 론}

상아질 이형성증은 상아질 형성에 장애가 생기는 질환으로 인구 100,000 명 당 1 명의 발병률을 나타내는 매우 드문 상염 색체 우성 유전질환이다 ${ }^{1-3)}$. 이 질환은 1920년에 Ballschmiede 에 의하여 가장 먼저 무근치(rootless teeth)로 서술되었으며 1933년 Rushton')에 의하여 상아질 이형성증(dentin dysplasia)으로 명명되었다. Shields 등이이 임상적 및 방사선학적으 로 나타나는 특징에 따라 두 가지 형으로 분류할 것을 제안하였 으며 그 후로 1972년 Witkop ${ }^{1)}$ 이 이환된 부위에 따라 치근형의 제 1 형과 치관형의 제 2 형으로 분류하였다. Witkop의 분류에 따른 상아질 이형성증의 임상 및 방사선학적 특징으로 제 1형 은 유치와 영구치 모두에 영향을 주며 임상적으로 정상적인 치
관형태를 나타내고 있으나 방사선학적으로 치수강의 폐쇄, 짧 고 원추형의 치근 또는 치근이 없는 양상으로 나타나기도 하며, 치수 잔사가 백악-법랑 경계에 평행되게 초승달 모양으로 관찰 되기도 한다. 또한 치아 우식증 및 치질 손상이 없는 건전한 치 아에서 종종 자발적으로 치근단 병소가 형성된다. 제 2형에서 는 유치와 영구치에서 임상 및 방사선학적 소견이 다르게 나타 난다. 임상적으로 유치의 치관은 상아질 형성부전증에서와 같 이 호박색, 회색 또는 유백색에 이르는 변색이 관찰되는 반면 영구치에서는 정상적인 치관을 나타낸다. 방사선학적인 특징으 로 제 2형의 유치에서는 제 1 형에서와 같이 치수강의 폐쇄를 보이나 영구치에서는 엉겅퀴관(thistle-tube)모양의 치수강과 치수석이 관찰된다.

상아질 이형성증의 발생 원인은 여전히 잘 알려져 있지 않으

\section{Corresponding author : Soonhyeun Nam}

Department of Pediatric Dentistry, School of Dentistry, Kyungpook National University, 2177 Dalgubeol-daero, Jung-gu, Daegu, 700-412, Korea

/ Tel: +82-53-600-7211/ Fax: +82-53-426-6608/E-mail: shnam@knu.ac.kr

Received October 7, 2013 / Revised October 22, 2013 / Accepted October 22, 2013

※ This research was supported by Kyungpook National University Research Fund, 2013. 
나 Logan 등근 치유두의 변성에 의하여 치수의 석회화가 일어 난다고 주장하였고 Sauk 등8)은 헤르트비히 상피근초(Hertwig's epithelial root sheath)의 조기 함입이 상아질 축적의 이상을 초래하였을 것이라고 제안하였다. 그러나 현재 가장 주목 받고 있는 가정은 제 1형 상아질 이형성증에서 나타나는 결함이 외 배간엽성 기원의 상아질 모세포의 비정상적인 기능과 분화에 의한 결과이며 이로 인해 치근 형태의 이상이 초래되었다는 것 이다 ${ }^{9)}$

상아질 이형성증에 의해 초래되는 치아의 조기 상실과 같은 치과적인 문제를 예방하기 위해서는 조기 진단이 중요하며 이 를 위해서는 방사선학적 검사가 반드시 필요하다. 특히 치아 형 태 이상을 유발하는 다른 질환과의 감별 진단이 필요하며 그 중 에서도 상아질 형성부전증과의 감별진단이 중요하다. 상아질 이형성증과 상아질 형성부전증은 모두 상염색체 우성 유전 질 환이며 상아질 형성부전증은 유치에만 이환되는 제 2형 상아질 이형성증과 달리 유치와 영구치 모두에 이환된 회색 또는 갈색 변색을 가진 유백색 치관이 특징적이며 그로 인해 심한 치아 마 모가 보인다. 또한 제 1 형 상아질 이형성증의 임상적인 소견은 정상적인 치관 형태와 색상을 가지는 것이 특징이다 ${ }^{10)}$.

이와 같이 제 1형 상아질 이형성증은 여러 가지 치과적 문제 를 가지고 있으나 발생이 드물고 더욱이 가족력에 대한 보고가 희소하다. 본 증례보고는 제 1 형 상아질 이형성증이 한 가족 내 에서 아버지를 제외한 4명의 가족 구성원들에게 이환된 증례들 을 관찰하였기에 이에 대한 임상적, 방사선학적 및 조직병리학 적 소견을 보고하고자 한다.

\section{II. 증례보고}

\section{1. 발단자(Proband)}

8세 2 개월 된 여아가 상악 영구 중절치의 치근부가 보이지 않는다는 주소로 개인치과의원에서 경북대학교 치과병원 소아 치과로 의뢰 되었다. 환아의 전신병력 상 특이 사항 없었으며 2 년 전 외력에 의한 치아 손상으로 상, 하악 양측 유중절치가 완 전 탈구된 치과적 병력이 있었다.

\section{1) 구강 검사(Dental examination)}

임상 검사 시 구강 위생이 불량하여 하악 양측 영구 중절치에 중등도의 치석이 침착되어 있었고 동요도가 보였으나 치관형태 의 이상은 관찰되지 않았다. 또한 전체적으로 정상적인 치관색 을 보였으나 상악 우측 유견치에서 다소 회갈색의 변색이 관찰 되었다(Fig. 1).

2) 방사선학적 검사(Radiographic examination)

정확한 진단을 위해 구외 파노라마 방사선 촬영과 구내 치근단 방사선 촬영을 시행하였다(Fig. 2, 3). 방사선사진에서 유치와 영구치 모두에서 전반적으로 짧고 불완전한 원추형의 치근 형태 와 근관 폐쇄가 관찰되었다. 또한 유치의 치근관은 완전히 폐쇄 가 되어 있었으며 영구치의 치근관은 방사선 투과성의 초승달 모 양의 치수 잔사가 백악-법랑 경계에 평행되게 관찰되었다. 또한 상악 양측 측절치와 하악 우측 측절치의 결손이 관찰되었다.
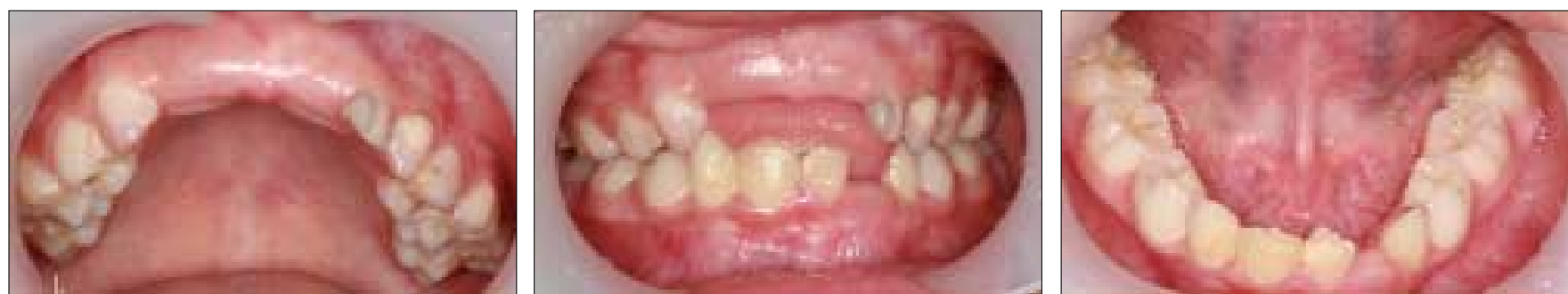

Fig. 1. Intra-oral views of proband show normal crown morphology and calculi deposition on the mandibular permanent central incisors. Note that all teeth have normal crown colors except the right maxillary deciduous canine is discolored gray-brown.

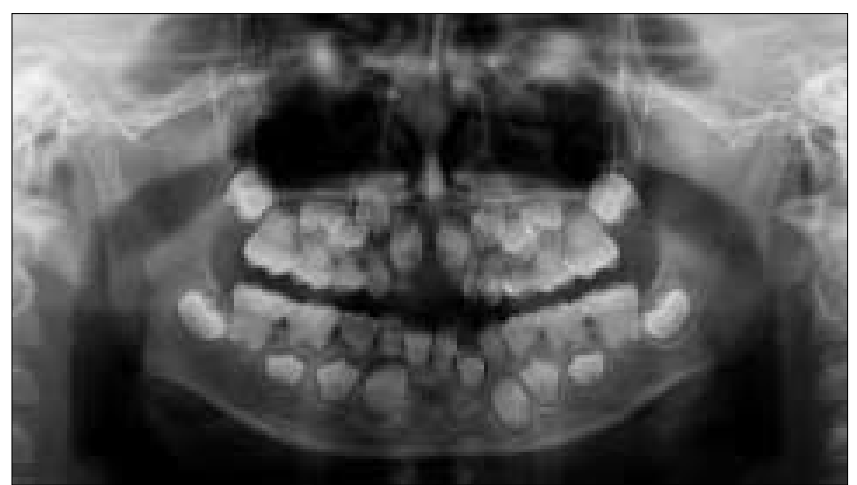

Fig. 2. Panoramic radiograph shows short, blunted, and cornical-shaped roots and obliteration of pulp chambers and canals.
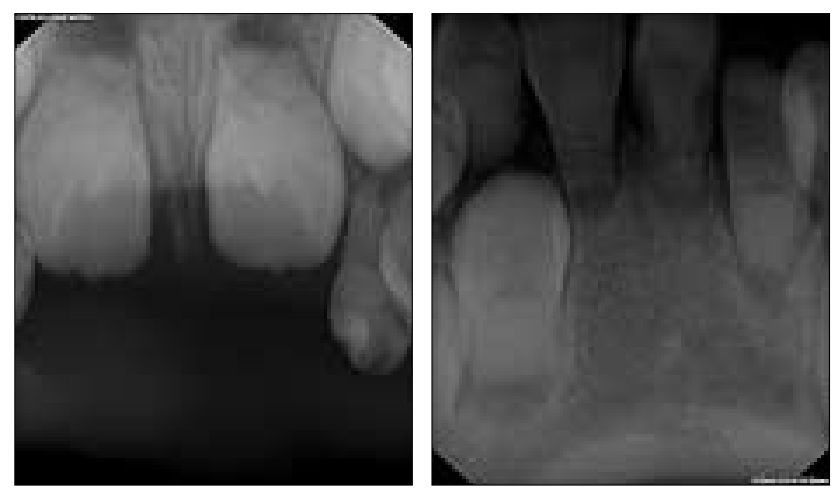

Fig. 3. Periapical radiographs show malformed and short roots on the maxillary and mandibular incisors. Pulp canals are almost obliterated and crescent-shaped pulp remnants are shown. 
3) 진단 및 치료(Diagnosis and treatment)

임상 및 방사선학적 특징들을 통하여 제 1형 상아질 이형성 증으로 진단하였다. 치료로는 환아의 구강 위생 상태를 개선하 기 위하여 치석제거술을 시행하였으며 정기 검진을 시행하기로 하였다.
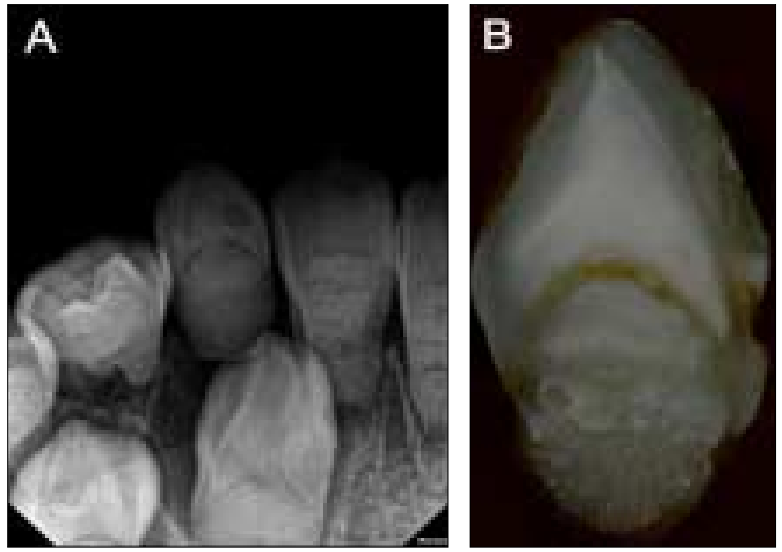

Fig. 4. (A) Periapical radiograph shows almost exfoliated right mandibular deciduous canine. (B) Ground section view of a extracted primary canine from the proband. Note normal outline of the tooth and normal enamel and coronal dentin. The crescent-shaped pulp remnant is showing approximately parallel to the cementoenamel junction, after which there is an abrupt change to dysmorphic dentin.
4) 조직병리학적 소견(Histopathological examination)

환아의 동요도가 증가된 하악 우측 유견치를 발거한 후 장축 방향으로 절단 하여 절편을 형성하였으며 그 절단면을 관찰하 였다(Fig. $4 \mathrm{~A}$ ). 정상적인 치아의 치관 외형과 법랑질 형성이 관찰되었으며 치관쪽 상아질과 일부 직하방 상아질은 정상적으 로 보였다. 그러나 치근쪽 상아질은 관상 상아질과 유골성 상아 질로 구성된 구상의 괴가 서로 유합되어 있었으며 이들 구상의 구조물은 마치 자갈위로 용암이 흘러내린 모양을 보였다. 또한 치관쪽 정상 상아질과 치근쪽 비정상적인 상아질 사이에는 초 승달 모양의 치수잔사가 관찰되었다(Fig. $4 \mathrm{~B}$ ).

\section{2. 형제(siblings)}

발단자의 2 명의 형제들에 대하여 임상 검사와 방사선 검사를 시행하였다. 전신병력 상 특이 사항 없었으며 구강 위생이 다소 불량하다는 것을 제외하고는 임상적으로 특이한 점이 관찰되지 않았다(Fig. 5, 6). 13세 6개월 된 첫째 오빠의 구외 파노라마 방사선 사진 상에서 발단자의 경우와 유사하게 전반적으로 짧 은 원추형의 치근이 확인되었으며 치수강과 치근관의 폐쇄가 관찰되었다. 또한 초승달 모양으로 형성된 방사선 투과성의 치 수 잔사가 백악-법랑 경계에 평행되게 관찰되었다(Fig. 7). 12 세 3 개월 된 둘째 언니의 구외 파노라마 방사선 사진에서 역시 짧고 불완전한 원추형의 치근 및 근관 폐쇄를 확인할 수 있었다 (Fig. 8). 형제들 모두 임상 검사 및 방사선학적 검사를 통하여 제 1형 상아질 이형성증에 이환되었음이 진단되었으며 부모의
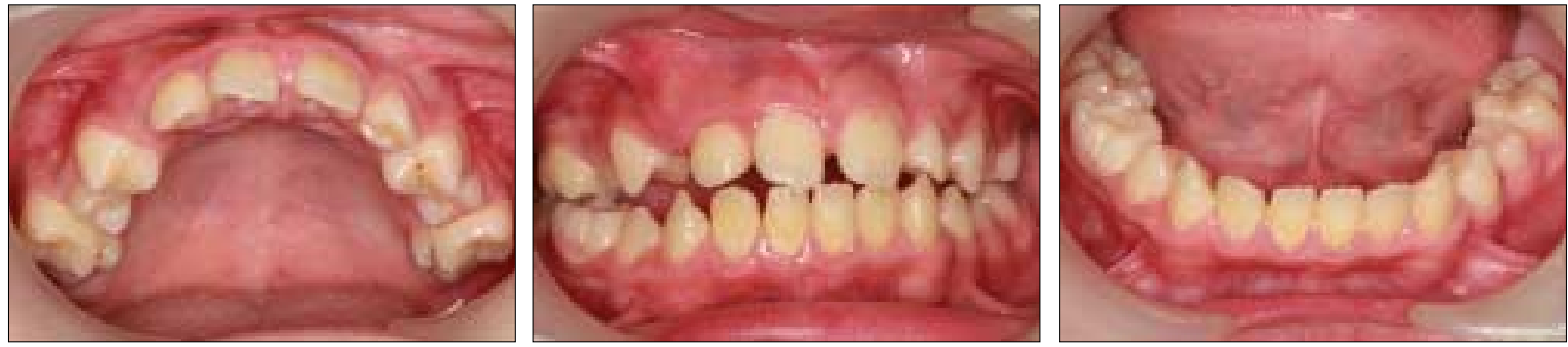

Fig. 5. Intra-oral views of proband's elder brother. Note normal crown morphology and color, and diasterma, prolonged retention of the right mandibular second deciduous molar, and calculi deposition on the mandibular permanent incisors are observed.
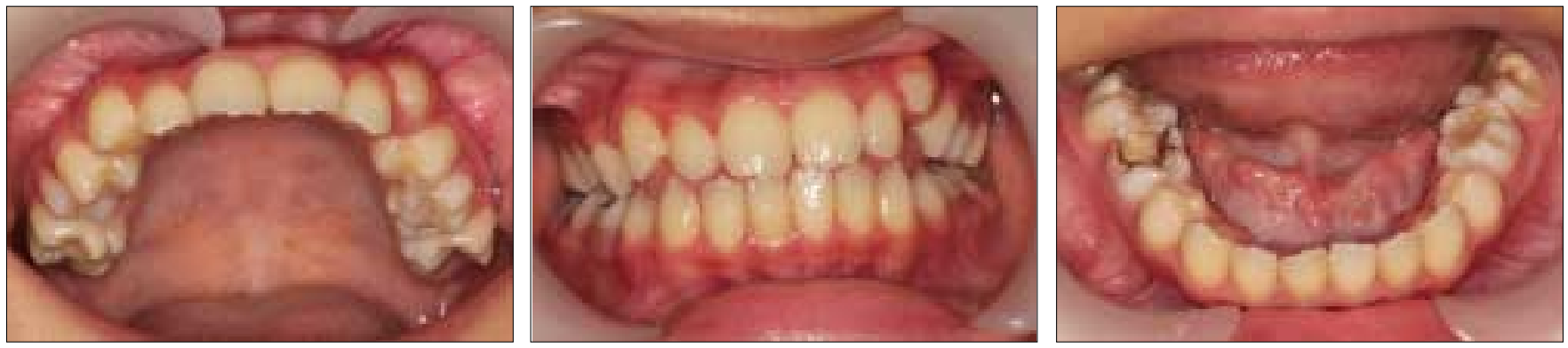

Fig. 6. Intra-oral views of proband's elder sister show normal crown color and morphology except the left mandibular permanent first molar affected enamel hypoplasia. 


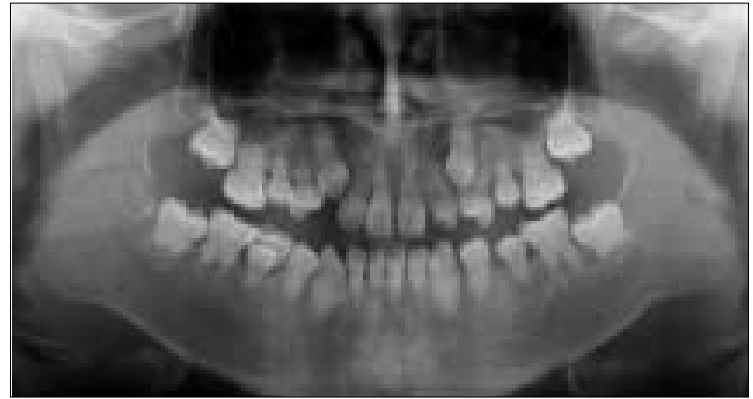

Fig. 7. Panoramic radiograph of proband's 13-year-old elder brother shows short, blunted and cornical shaped roots and obliteration of pulpchambers and canals.

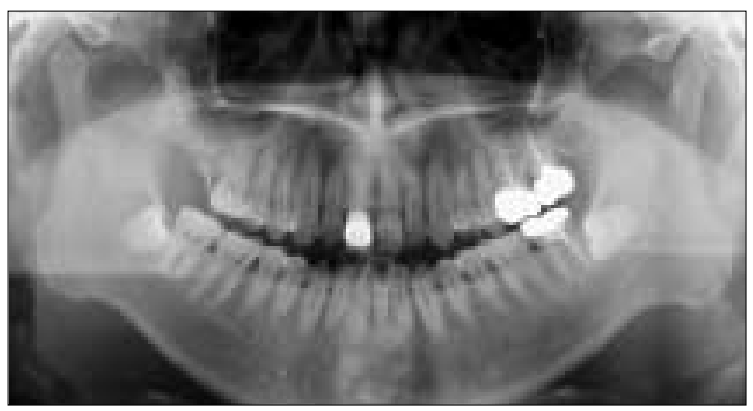

Fig. 9. Panoramic radiograph of proband's father shows normal crown and root morphology. Dental defects, carious lesions and residual root are observed, but normal pulp chambers and canals are shown.

치과적 검사를 통해 유전 경로를 확인하고자 하였다.

\section{3. 부모(Parents)}

환아 아버지의 구외 파노라마 방사선 사진에서는 상악 우측 제 2 대구치의 잔존 치근, 상악 우측 측절치, 상악 좌측 중절치 와 측절치, 하악 우측 견치의 치아 우식이 발견되었으며 매복된 하악 양측 제 3대구치를 확인할 수 있었으나 치근과 치근관의 형태는 모두 정상임을 확인할 수 있었다(Fig. 9). 그에 반하여 43세인 환아 어머니의 구외 파노라마 방사선 사진에서는 자녀 들에게서와 비슷한 치근의 형태학적 이상이 발견되었다. 전반 적으로 짧으며 하악 구치부에서의 특징적인 $\mathrm{W}$ - 자 모양의 치 근이 관찰되었으며 치수강과 치근관의 완전한 폐쇄가 관찰되었 다. 상악 좌측 중절치와 하악 우측 측절치의 결손에 의한 계속 가공 의치 장착하였으며 하악 우측 제 1 대구치와 제 2 대구치에 는 원인이 명확하지 않은 치근단 병소가 관찰되었다. 이러한 방 사선학적 소견에 근거하여 어머니 역시 제 1 형 상아질 이형성 증으로 진단하였다(Fig. 10).

제 1형 상아질 이형성증에 이환된 4명의 가족들에 대해서는 정기적인 구강검진 및 구강위생관리가 필요하며 정기적인 불소 도포와 예방적인 수복치료가 필요함을 설명하였다.

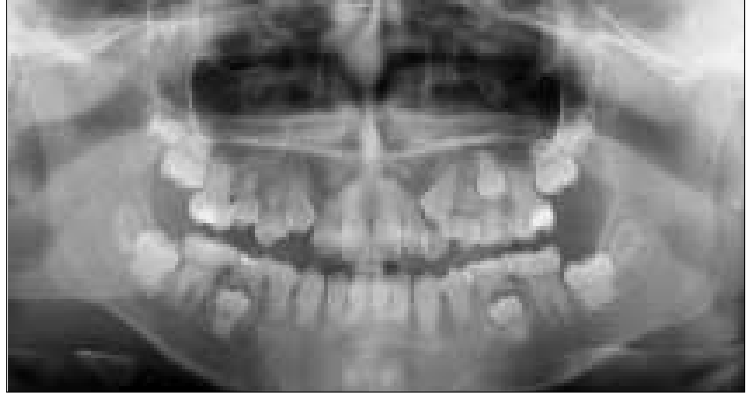

Fig. 8. Panoramic radiograph of proband's 12 -year-old elder sister. Note short, blunted and cornical shaped roots and severe calcification and obliteration of the pulps.

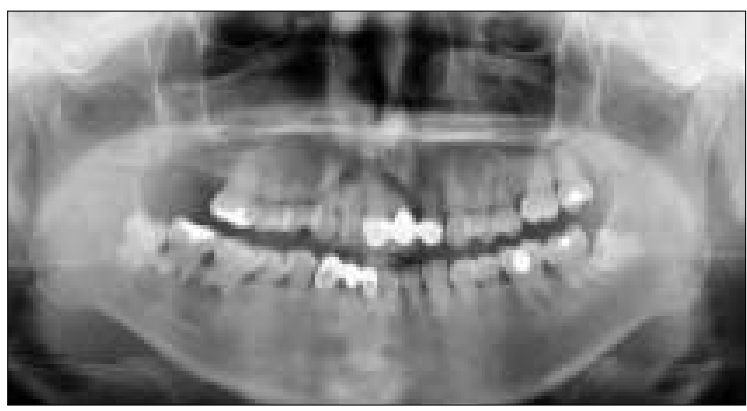

Fig. 10. Panoramic radiograph of proband's affected mother. Note severe calcification and obliteration of the pulps and periapical radiolucecies on the intact right mandibular first and second molars. Short, blunted, and cornical shaped roots on the entire dentition and $\mathrm{W}$-shaped roots on the mandibular posterior teeth are observed.

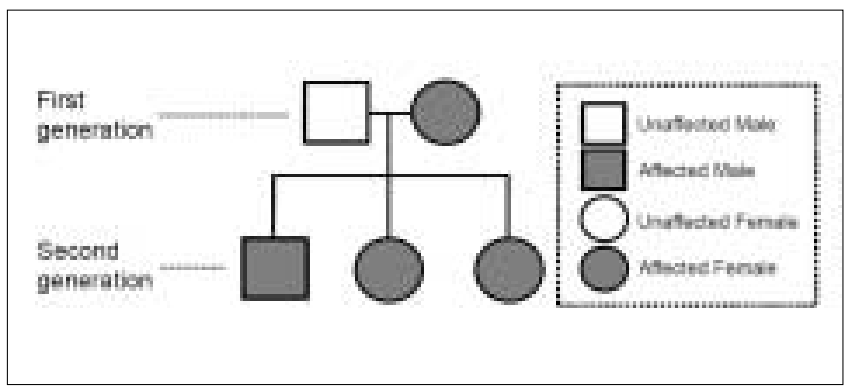

Fig. 11. Pedigree of this family shows autosomal dominant trait with high degree of penetrance.

\section{4. 가계도(Pedigree)}

본 증례보고에 소개된 가족의 가계도를 통하여 가족 내에 이 환된 제 1형 상아질 이형성증이 상염색체에 대하여 우성으로 유전되었으며 높은 침투도로 유전되었음을 확인할 수 있었다 (Fig. 11). 


\section{III. 총괄 및 고찰}

제 1형 상아질 이형성증의 정확한 발생에 대해서는 여전히 밝혀지지 않았다. 상염색체 우성 유전 질환으로 알려져 있으나 가족력을 가지며 발생한 증례는 흔치 않으며 10.16.17) 가족력을 가지 지 않고 산발적으로 발생한 증례들은 종종 보고 되고 있다.111-13). 본 증례보고에서는 이환된 어머니와 이환되지 않은 아버지 사 이에 태어난 모든 자녀에게서 제 1형 상아질 이형성증이 나타 났으며 이를 통해 가족력에 의해 발생되었음을 확인할 수 있었 다. 제 1형 상아질 이형성증의 정확한 발생학적 기전에 대해서 는 여러 주장들이 있으며 Logan 등근 치유두의 변성에 의하여 치수의 석회화가 일어난다고 주장하였고 Sauk 등은 헤르트비 히 상피근초(Hertwig's epithelial root sheath)의 조기 함입 이 상아질 축적이상을 가져왔을 것이라고 추측하였으나 현재는 Wesley 등 ${ }^{14}$ 이 주장한 상아질 이형성증 제 1형에서 나타나는 결함이 외배간엽성 기원의 상아질모세포의 비정상적인 기능과 분화에 의한 결과로 치근 형태의 이상이 초래되었을 것이라는 것이 주목받고 있다.

상아질 이형성증은 종양성 피부석회증(Tumoral calcinosis) 과 동반되기도 한다는 몇몇의 보고가 있다 ${ }^{15.16)}$. 또한 엘러스-단 로스 증후군(Ehlers-Danlos syndrome), 엘리스-반 크레벨드 증후군(Ellis-Van Creveld symdrome)과 상아질 형성부전증 을 동반한 골형성부전증 등에서도 상아질 이형성증이 나타날 수 있기 때문에 이에 대한 감별진단이 필요하다. 그러나 본 증 례에서 보고된 4 명의 환자에서는 전신적인 증상을 동반하는 위 와 같은 증후군에 이환되지 않았다.

제 1형 상아질 이형성증을 방사선 투과성으로 관찰되는 치수잔 사의 형태에 따라 4 가지의 아분류로 구분하자는 제안이 있다 ${ }^{18)}$. 그러한 분류에 따르면 치수잔사의 크기 및 형태 그리고 치근의 길이에 따라 아분류 $1 \mathrm{a}$ 에서 $1 \mathrm{~d}$ 까지 나누었다. 그러나 본 증례 에서도 확인할 수 있듯이 한 명의 환자에게서도 여러 개의 아분 류가 나타나게 된다. 즉, 셋째 자녀의 유치에서는 완전 폐쇄를 보이는 아분류 $1 \mathrm{a}$ 가 나타나지만 영구치에서는 $1 \mathrm{~b}-1 \mathrm{c}$ 로 분류가 된다. 그러므로 이러한 아분류는 임상적으로 큰 의미를 가지지 않는 것으로 생각된다. 또한 유치에서 관찰되는 방사선 투과성 의 치수잔사가 영구치보다 더 적다는 것은 몇 개의 증례에서 보 고가 된 바 있으며 Kalk 등근 5 명의 증례를 통해서 나이가 어 릴수록 관찰되는 치수잔사가 더 명확하고 크며 나이가 들수록 줄어들고 성인에 있어서는 거의 보이지 않았다고 보고하였다. 본 증례에서도 역시 나이가 가장 어린 셋째 자녀에서 뚜렷한 치 수잔사가 관찰되었으며 나이가 증가할수록 치수잔사 부위가 줄 어들다가 성인인 어머니에서는 거의 관찰할 수 없었다. 이는 치 아가 맹출 후 치수강의 폐쇄를 유도하는 이차 상아질의 축적에 의한 것으로 추측되고 있다 ${ }^{17)}$.

제 1형 상아질 이형성증은 방사선학적으로 짧은 원추형의 치 근, 치수강과 치근관의 폐쇄, 건전한 치아의 자발적 치근단 병 소의 형성 및 구치부위의 $\mathrm{W}$-자 모양의 치근형태와 같은 특징들 을 통해 진단할 수 있다. 그에 반해 임상적으로는 정상치아와
크게 다른 점을 발견할 수 없다. 그러나 위에서 언급한 맹출 지 연, 치아의 비정상적인 동요도, 호박색 및 회색의 치관 ${ }^{16}$ 그리고 절단부위의 불투명함 ${ }^{17)}$ 이 관찰될 경우 정상적인 치관형태와 강 도를 보일지라도 방사선학적 검사를 통한 정확한 평가 및 진단 이 필요할 것이다. 본 증례에서는 발단자인 셋째 자녀의 상악 우측 유견치에 다소 붉은색의 변색이 관찰되었으나 다른 자녀 와 어머니에서는 특이한 변색은 관찰되지 않았다.

제 1형 상아질 이형성증에 이환된 경우 드물게 맹출 지연이 나타나기도 한다. Kalk 등 ${ }^{17}$ 이 보고한 5 명의 제 1 형 상아질 이 형성증 환자에게서 모두 맹출지연이 관찰되었으며 이는 맹출에 있어 필수적인 치근의 성장이 정상적으로 이루어지지 않았기 때문일 것이라고 하였다. 본 증례보고에서 셋째 자녀의 경우 환 아의 연령에 비해 맹출이 다소 지연되고 있음이 관찰되었으나 그 정도는 심각하지 않았으며 이갈이가 거의 완료된 나머지 두 자녀들과 영구치열기인 어머니에서는 맹출 지연을 확인할 수는 없었다.

제 1형 상아질 이형성증 환자에서 종종 나타나는 치근단 병 소의 경우 치과적인 치료가 어렵다. 이러한 치근단 병소는 치수 강 및 치근관의 폐쇄에 따른 무균성 치수괴사에 의한 것으로 여 겨지며 이러한 병소의 치료에 있어 고려하여야 할 점은 치근의 길이에 대한 평가이다. 전통적인 근관치료를 시도한 보고들이 있으나 ${ }^{1920)}$ 짧은 기간 동안의 성공률만이 보고되었으며 이들도 모두 양호한 치근 길이가 있을 경우에 시도가 되었다. Coke 등 ${ }^{19)}$ 은 치근단 소파술과 치근단 역충전술을 시도해 보았으며 2 개 월간의 양호한 결과를 보고하였으나 이러한 술식들 역시 상대 적으로 양호한 치근 길이가 있을 경우 행해져야하며 긴 시간동 안의 치료 예후는 아직 보고된 바 없다. 그러므로 일반적으로 치근단 병소가 생긴 제 1형 상아질 이형성증 환자에 있어 해당 치아의 치료는 발치가 권장된다. 본 증례보고에서 어머니의 경 우 하악 우측 제 1 대구치와 제 2 대구치에서 치근단 병소가 관 찰되었으며 짧은 치근과 치주인대 부착의 불리한 조건뿐 아니 라 근관의 심각한 폐쇄로 인하여 근관치료의 적응증이 되지 못 하며 발치가 필요할 것으로 생각되어진다.

제 1형 상아질 이형성증의 임상적 문제 중 하나는 짧은 원추 형의 치근으로 인한 동요도 및 조기 탈락이다. 그러므로 치주인 대의 부착 상실을 예방하기 위해서 철저한 치태 관리, 국소적 불 소 도포와 홈메우기 같은 예방 치료 및 환자에 대한 구강 위생 관리 교육이 강조된다. Steidler 등이는 예방치료가 1형 상아질 이형성증 환자를 관리하는 데 있어 중요하며 정기적인 검진을 통해 치주적인 문제와 치아 우식증을 예방하여 치아가 가능한 오랜 기간 유지될 수 있도록 치과적 관리가 필요하다고 하였다.

제 1형 상아질 이형성증은 굉장히 드물게 발생하는 유전질환이 며 가족력을 가진 증례에 대한 보고는 현재까지 흔치 않다 ${ }^{10,16,17)}$. 방사선학적 검사를 통하여 제 1형 상아질 이형성증의 특징적인 소견들이 나타날 경우 다른 가족구성원들에 대한 검사를 시행 해 보는 것이 바람직하며 제 1 형 상아질 이형성증으로 진단될 경우에는 치아의 조기 상실을 예방하기 위한 정기적인 구강 관 리가 반드시 필요할 것으로 생각된다. 


\section{IV. 요 약}

제 1형 상아질 이형성증은 드물게 발생하는 상염색체 우성 유전 질환으로 유치와 영구치에 모두 이환되며 짧은 치근 및 불 량한 구강 위생 관리로 인한 치주적인 문제가 동반될 경우 치아 의 조기 탈락을 초래한다. 본 증례보고에서는 한 가족 내에서 아버지를 제외한 4 명의 가족구성원에서 발생한 제 1 형 상아질 이형성증을 살펴보았다. 조기 진단 및 예방치료는 제 1형 상아 질 이형성증에 이환된 치아의 유지 및 관리에 있어 중요하다. 이러한 관점에서 소아치과 의사들은 중요한 역할을 가지게 되 며 제 1형 상아질 이형성증에 이환된 치아들을 좀 더 오래 유지 하기 위해 철저한 구강위생 교육 및 예방적 처치가 필요할 것으 로 생각된다.

\section{References}

1. Witkop-Jr CJ : Hereditary defects of dentin. Dent Clin North Am, 19:25-45, 1975.

2. Stewart RE, Prescott GH : Text book of oral facial genetics. Mosby Co., St. Louise, 237-239, 1976.

3. Kim JW, Simmer JP : Hereditary dentin defects. $J$ Dent Res, 86:392-399, 2007.

4. Ballschmiede : Malformations of the jaws and teeth. New York, Oxford University Press, 286, 1930.

5. Rushton MA : A case of dentinal dysplasia. Guys Hosp Rep, 89:369-73, 1939.

6. Shields ED, Bixler D, El Kafrawy AM : A proposed classification for heritable human dentine defects with a description of a new entity. Arch Oral Biol, 18:543-553, 1973.

7. Logan J, Becks H, Pindborg JJ, et al. : Dentinal dysplasia. Oral Srug Oral Med Oral Pathol, 15:31733, 1962.

8. Sauk JJ, Lyons HW, Witkop CJ, et al. : An electron optic analysis and explanation for the etiology of dentin dysplasia. Oral Surg Oral Med Oral Pathol, 33:763-771, 1972.

9. Melnick M, Levin LS, Brady J : Dentin dysplasia type I : a scanning electron microscopic analysis of the primary dentition. Oral Surg Oral Med Oral Pathol, 50:335-340, 1980.
10. Seow WK, Shusterman S : Spectrum of dentin dysplasia in a family : case report and literature review. Pediatr Dent, 16:437-442, 1994.

11. Shohreh Ravanshad, Akbar Khayat : Endodontic therapy on a dentition exhibiting multiple periapical radiolucencies associated with dentinal dysplasia type 1. Aust Endod J, 32:40-42, 2006.

12. Ryu JA, Kim SH, Lee JH, $t$ al. : Dentin dysplasia type I: a case report. J Korean Acad Pediatr Dent, 34:718-724, 2007.

13. Toomarian L, Mashhadiabbas F, Mehrdad L, et al. : Dentin dysplasia type I: a case report and review of the literature. J Med Case Rep, 4:1-6, 2010.

14. Wesley RK, Wysocki GP, Jackson J, et al. : Dentinal dysplasia Type I: clinical, morphology and genetic studies of a case. Oral Surg Oral Med Oral Pathol, 41:516-524, 1976.

15. Morris ME, Augsburger RH : Dentine dysplasia with sclerotic bone and skeletal anomalies inherited as an autosomal dominant trait. Oral Surg Oral Med Oral Pathol, 43:267-283, 1977.

16. Ansari G, Reid JS : Dentinal dysplasia type I: review of the literature and report of a family. ASDC J Dent Child, 64:429-434, 1997.

17. Kalk WW, Batenburg RH, Vissink A : Dentin dysplasia type I: Five cases within one family. Oral Surg Oral Med Oral Pathol Oral Radiol Endod, 86:175-178, 1998.

18. O'carroll MK, Duncan WK, Perkins TM : Dentin dysplasia: review of the literature and a proposed subclassification based on radiographic findings. Oral Surg Oral Med Oral Pathol, 72:119-125, 1991.

19. Coke JM, Del Rosso G, Van Cura JE, et al. : Dentinal dysplasia, Type I: Report of a case with endodontic therapy. Oral Surg Oral Med Oral Pathol, 48:262-268, 1979.

20. Steidler NE, Radden BG, Reade PC : Dentinal dysplasia: A clinicopathological study of eight cases and review of the literature. Br J Oral Maxillofac Surg, 22:274-286, 1984. 
국문초록

\title{
가족 내에 발생한 제 1형 상아질 이형성증: 증례보고
}

\author{
김소현 · 김영진 · 김현정 · 남순현
}

경북대학교 치의학전문대학원 소아치과학교실

상아질 이형성증은 매우 드물게 발생하는 상염색체 우성 유전 질환이다. 발생학적 원인에 대해서는 아직 명확하게 알려지 지 않았으며 인구 100,000 당 1 명의 발병률을 나타낸다. 상아질 이형성증은 두 가지 형으로 분류가 되며, 치근부위 상아질 형성이상을 보이는 치근형의 제 1 형과 치관부위 상아질 형성이상을 보이는 치관형인 제 2 형으로 나눠진다. 제 1 형 상아질 이 형성증은 임상적으로 정상적인 치관형태을 보이고 있으나 동요도를 가지며 방사선학적으로 치수강과 치근관의 폐쇄, 짧은 원 추형의 치근형태 및 자발적으로 형성된 치근단 병소가 특징적으로 관찰된다.

본 논문은 한 가족 내에서 아버지를 제외한 4 명의 가족 구성원들에게 발생한 제 1 형 상아질 이형성증을 관찰한 바, 이에 대해 이환된 가족 구성원들의 임상, 방사선학 및 조직병리학적 소견을 보고하고자 한다.

제 1형 상아질 이형성증은 방사선학적 검사를 시행하지 않고서는 임상적으로 인지하기 어려우며 조기 진단을 통해 정기적 인 구강 위생 관리 및 예방치료를 시행할 경우 이환된 치아의 조기 탈락을 예방하거나 지연시킬 수 있을 것이다.

주요어: 상아질 이형성증, 유전 질환, 무근치 